\title{
Clinical Effect of Kasisadi Taila in the Management of Post Operative Wound of Infected Sebaceous Cyst- A Case Report
}

\author{
Hetal Nakrani ${ }^{1}$, Dr. T. S. Dudhamal ${ }^{2}$ \\ ${ }^{1}$ M.S. 2nd year Scholar, ${ }^{2}$ Asso. Prof. \& I/C HOD \\ Department of Shalya tantra, Institute for Post Graduate Teaching and Research in Ayurveda (IPGT\&RA), \\ Gujarat Ayurved University, Jamnagar, Gujarat, India
}

*Corresponding Author: Hetal Nakrani, M.S. 2nd year Scholar, Department of Shalya tantra, Institute for Post Graduate Teaching and Research in Ayurveda (IPGT\&RA), Gujarat Ayurved University, Jamnagar, Gujarat, India

\begin{abstract}
Vrana is defined as discontinuation of tissues. Any injury leads to destruction of more than one epithelium requires suitable medicament for formation of new tissue i.e. the granulation tissue, which progressively gets transformed into a mature fibrous scar. Though wounds including surgical wounds with or without tissue loss heal by basic biological process but proper topical application makes a favorable atmosphere for early healing. Under the context of wound management, Kasisadi Taila has been recommended by Ayurveda to manage to all types of Vrana. A 50 years old female patient admitted in Shalya female ward with complaints of swelling at right gluteal region since last 7 months. The pain in right gluteal region was initiated since one week so she consulted to hospital. She was operated for similar problem before one year. Local examination reveals the big spherical swelling at right upper quadrant of gluteal region; approximately of size $8 \mathrm{~cm} \times 7 \mathrm{~cm}$, non movable with presence of tenderness was noted. The case was provisionally diagnosed as infected sebaceous cyst. Ultrasound report also revealed the case as sebaceous cyst. She was posted for surgery and whole cyst was excised under spinal anesthesia. The base tissue was calcified, the wound was not closed and planned to use Kasisadi Taila application locally in routine dressing to promote secondary healing she was treated successfully with local application of Kasisadi taila. Triphala guggulu 1 gm three times a day was given orally with luke warm water for initial one month. The relief in signs and symptoms were assessed by weekly interval on scoring pattern. The wound was healed smoothly within two and half month without any signs of infection. The case study highlighted that secondary healing in a Shuddha Vrana (post operative wound) can be easily managed by local application of Kasisadi Taila.
\end{abstract}

Keywords: Shuddha vrana, Kasisadi taila, wound, sebaceous cyst, Triphala Guggulu

\section{INTRODUCTION}

Wound healing is a natural restorative response to tissue injury healing is the interaction of a complex cascade of cellular events that generals resurfacing, reconstitution and restoration of the tensile strength of injured skin. Healing is a systemic process, traditionally explained in terms of their classic phases Viz. inflammation, proliferation, and maturation. A clot form and inflammatory cells debrides injured tissue during the inflammatory phase. Epithelization, fibroplasias, and angiogenesis occur during the proliferative phase. Mean while granulation tissue forms and the wound healing to contract. Finally, during the maturation phase, collagen forms tight cross links to other collagen and with protein molecules, increasing the tensile strength of the scar. For the sake of discussion and understanding, the process of wound healing may be considered a series of separate events. In actuality, the entire process is much more complicated as cellular events that lead to scar formation occur in tandem. Many aspects of wound healing have yet to be elucidated.

A sebaceous cyst is a lump that forms in the outermost layer of skin. It develops when an oil- producing gland in skin is blocked, creating a hollow sac filled with fatty, yellowish substance that looks like cottage follicles or lumps that result from skin trauma. Sebaceous cysts are usually harmless, but an infected sebaceous cyst can be painful brought the patient to surgeon. Sebaceous cyst is a movable, painless lump that is often growing under skin. However, sometimes, it can become infected due to trauma or repeated contact with bacteria. Typical signs and symptoms of an infected sebaceous cyst include tenderness, redness, hot feeling over the affected skin, and grayish white stuff with bad smell from the lump. 
The major aspect of management of the fresh wound is prevention of the infection and speedy healing; reducing pain, discharge and less discoloration after healing are the other important factors. Post operative normal wound healed by primary intension after suturing. But in infected cases suturing is not advisable and wound kept open for healing with secondary intension. This case planned to evaluate the healing potency of Kasisadi taila in the management of post operative wound of infected sebaceous cyst.

\section{Clinical CASE PRES ENTATION}

A female patient of 50 years visited OPD of Shalya tantra IPGT \& RA Hospital, Jamnagar complaining of swelling at right gluteal region for 7 months. The swelling was increased in size gradually, pain in right gluteal region for 1 week and pricking type pain and pain referred to left leg. Patient reported history of excision ofr sebaceous cyst for two times in the interval of one year in civil hospital. One month ago she was noticed whitish thick discharge with foul smelling coming from wound. So she consulted Shalya tantra OPD for Ayurved management. Patient was admitted for further investigation, diagnosis and proper management. Local examination showed a big spherical swelling at right upper quadrant of gluteal region, approximately the size $8 \mathrm{~cm} \times 7 \mathrm{~cm}$, non movable with presence of tenderness. She was provisionally diagnosed as infected sebaceous cyst (Fig-1). Ultrasound report revealed this case as sebaceous cyst. On investigations, haematological and biochemical values were found within normal limit. All systemic examinations were within normal limit having vital data BP $126 / 80 \mathrm{~mm}$ of $\mathrm{Hg}$. So the case was final diagnosed as infected sebaceous cyst. She was posted for surgery and whole deep seated cyst was excised under spinal anesthesia. The post surgical wound was not closed because cyst was infected and big size wound. As the case was recurrent two times so instead of conventional dressing with antiseptic we planned to use Kasisadi Taila locally in routine dressing to promote secondary healing.

\section{Preparation of Kasisadi OIL}

The Kasisadi oil was prepared by adopting classical reference of Taila Kalpana. ${ }^{[1]}$ The ingredients of Kasisadi Taila are mineral drugs Kasisa, Manashila along with Saindhava lavana and gomutra and herbal drugs- Langali, Kushta, Shnuti, Pippali, Ashwamara, Vidanga, Chitraka, Dhuma, Danti, Koshathaki Beeja, Hemahva, Snuhi processed in tila taila as per standard taila preparation methods (Table-1).

Table1. Ingredients of Kasisadioil

\begin{tabular}{|l|l|l|}
\hline Ingredients & Botanical name & Part used \\
\hline Kasisa & Ferrous sulfate (FeSo4) & Mineral \\
\hline Langali & Gloriosa suprba Linn & Mula (root) \\
\hline Kushtha & Sausserea Leppa C.B. Clarke & Mula (root) \\
\hline Sundhi & Zingiber officinale Roscoe & Kanda $($ Stem) \\
\hline Pippli & Piper longum Linn. & Fala (Fruit) \\
\hline Sandhav & Sodium chloridum & Mineral as such \\
\hline Manhshila & Arsenic disulphide (As3As2) & Mineral as such \\
\hline Karvira & Nerium indicum Soland & Mula (root), Bija (seed), pushpa (flower) \\
\hline Vidang & Embelia ribes Burm. f. & Bija (seed) \\
\hline Chitraka & Plumbego Zeylanica Linn & Bija (seed) \\
\hline Koshataki & Luffa acutangula Roxb. & Bija (seed) \\
\hline Danti & Baliospermum montanum Muell. & Mula (root) \\
\hline Snuhi & Euphorbia neriifolia Linn. & Kshira (latex) \\
\hline Tila taila & Sesamum indicum Linn. & Bija (seed) \\
\hline
\end{tabular}

\section{WOUND DRESSING}

The patient was advised for sitz bath daily with freshly prepared Panchwalkal Kwath before dressing.

${ }^{[2]}$ Shodhan properties of Panchavalkal help to clean the wound. ${ }^{[3]}$ In the dressing room the wound was first clean with normal saline (NS) then the cotton gauze soaked in Kasisadi oil and was applied in the base of wound and fill the whole wound cavity so that the raw area should not remained. The wound was covered with sterile gauze piece and then bandaged. This procedure was followed daily once in the morning under aseptic condition till complete healing of wound. Along with the local dressing Triphala Guggulu (500mg) 2 tablets three times a day was given with luke warm water for four weeks. 


\subsection{Outcome}

The wound size after excision of sebaceous cyst was $8 \mathrm{~cm} \times 7 \mathrm{~cm} \times 5 \mathrm{~cm}$ (Fig-2). Day after excision of sebaceous cyst cleaning with NS and dressing with betadine solution was started. But after 3 days it was noticed that there was slough at the base of wound and foul smelling discharge from wound. So we planned to dressing with Kasisadi oil. The wound was first cleaned with freshly prepared Panchwalkala $k$ watha and dressing was done with Kasisadi taila packing in wound daily. The wound was observed for its size, slough, discharge, edges, and margins daily and recoded in proforma by weekly interval. The wound was observed and assessed daily for healthy granulation tissue as well as wound healing promoted from base within 7 day. The wound size was observed to be reduced with contracted margins without any complication. The wound healed completely with normal scar after two months.

\section{Images of Wound Healing}

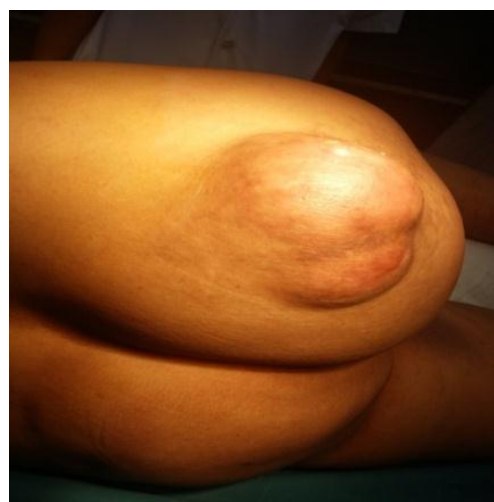

Fig1: Sebaceous cyst before excision

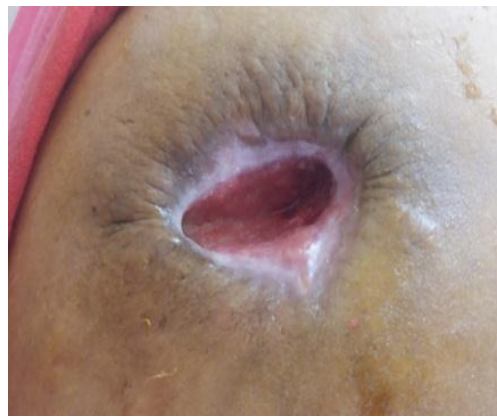

Fig4. Wound status after one and halfmonth

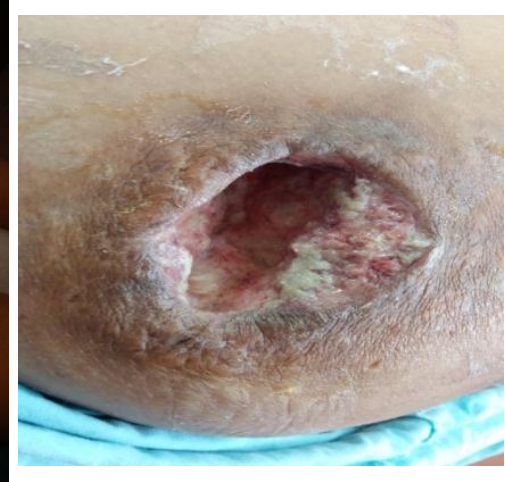

Fig2. After excision of cyst under SA on $3 d$ day

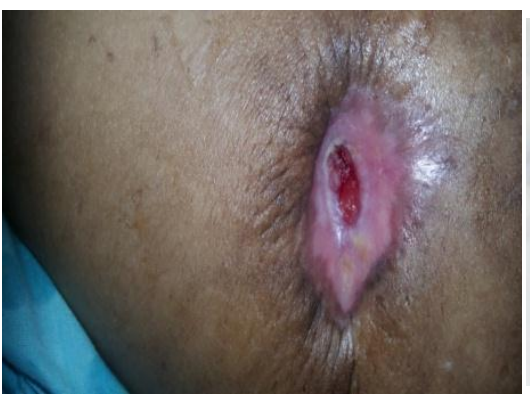

Fig5. Wound contraction and healing stage after 2 months

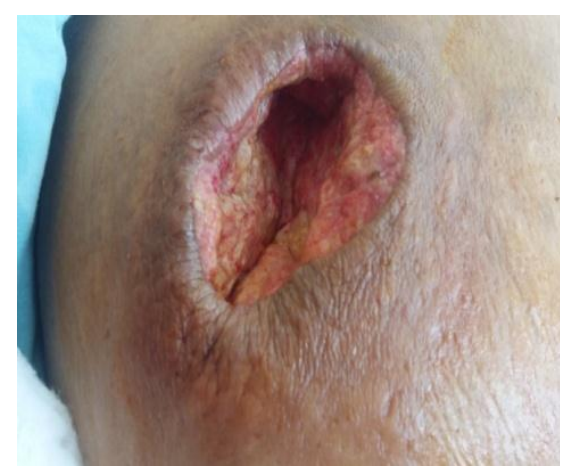

Fig3. wound status after one month

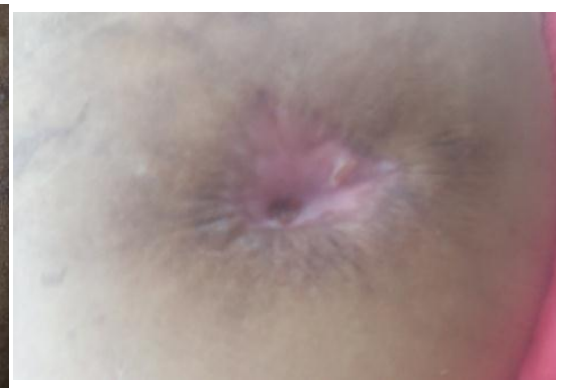

Fig6. Complete healed wound after two and half months

\section{DIS CUSSION}

In this case the conventional dressing was changed with Kasisadi Taila as previously history of recurrence and wound was not responsding to dressing with betadine. The most of the ingredients of Kasisadi taila have Ushna, Tikshna, Lekhana and shodhanhara properties. These properties helpedto scraping out the slough and dead tissue as well as reduce the inflammation. Kasisa (Ferrous sulfate FeSo4) have Krumighana (antimicrobial) property which helped to control the infection and also for wound contraction. ${ }^{[4]}$ Manhashila (Ferri sulphos) have katu- tikta and snigdha-usna-guru guna which exhibits lekhana property so it remove the sebaceous cyst sac portion removal from base of the wound. ${ }^{[5]}$ Kasisa, Kushtha and Chitrak ${ }^{[6]}$ have a lekhan properties so slough, pus, unhealthy granulation tissue is debrided and wound become healthy with eovascularization and normal granulation. Karvir have Vranalaghavakar property. ${ }^{[7]}$ Vidang have Krumigna and also Jantunashak (antibacterial) property so wound become free from any outside of bacteria. ${ }^{[8]}$ So chance of wound infection was minimized a which promote the wound healing. Chitraka and Danti have also Krumighna property. ${ }^{[9-10]}$ In nutshell it can be hypothesized that all ingredients of Kasisadi taila play combine effect of Shodhan, Lekhan and Ropan activity and wound healed without recurrence. In Ayurved classic the Kasisadi taila is indicated in the management of arsha (Piles) but in recent researches it has been also shown the healing potential in dushta vrana. ${ }^{[1]}$ Panchvalkal kwath was used for sitz bath also played important role in 
maintaining local hygiene, Sodhana as well as Ropan of the wound. ${ }^{[12]}$ Triphala Guggulu possesses analgesic and anti- inflammatory property which reduce the local pain and inflammation. ${ }^{[13]}$

\section{CONCLUSion}

This single case study concluded that Kasisadi oil possesses Shodhan (Cleaning), Lekhan (Scraping/debride), Ropan (healing) properties and had potential to heal post operative wound of infected sebaceous cyst. This is single case study need to be validated with controlled trial in future.

\section{REFERENCES}

[1] Shreemati Shailaja Shreevastav, Sharangadar Samhita, Madhyam Khand 9/ Chaukhambha Oriayantaliya, Varanasi, publication 2011, page- 215.

[2] Krushna Chandrakar, Bhavprakash Nighantu Vatadivarga-5/15 Chaukhambha Bharati academy, Varanasi2010, page-507

[3] Bhat KS, Vishwesh BN, sahu M, Shukla VK. A clinical study on the efficacy of panchavalkala cream in vrana shodhana w.s.r to its action on microbial load and wound infection. AYU. 2014; 35:135-40.

[4] Sadananda Sharmna, Rasatarangini, 21/232 Kashinathsha Shtrina Sampadita, Dilhi, 11 ${ }^{\text {th }}$ ed. 1971 page-564.

[5] Sadananda Sharmna, Rasatarangini 11/115, Kashinathsha Shtrina Sampadita, Dilhi, 11 $1^{\text {th }}$ ed. 1971 page 263

[6] Charak Charak Samhita Part-1 Sutrasthan 4/3, Chaukhambha Bharati Academy, Varanasi, 2017, page 72.

[7] Krushna Chandrakar, Bhavprakash Nighantu, Guduchyadivarga-2/84 Chaukhambha Bharati Academy, Varanasi- 2010, p- 300.

[8] Krushna Chandrakar, Bhavprakash Nighantu, Haritakyadi varga-1/111 Chaukhambha Bharati academy, Varanasi- 2010, p-50.

[9] Krushna Chandrakar, Bhavprakash Nighantu, Haritakyadivarga 1/71 Chaukhambha Bharati academy, Varanasi- 2010 p-21.

[10] Krushna Chandrakar, Bhavprakash Nighantu, Guduchyadivarga-3/200 Chaukhambha Bharati academy, Varanasi- 2010, p-385.

[11] Mashetti NB. Effect of kasisdi taila in Dushta Vrana. Journal of Ayurved and Integrated medical sciences 2017;2(3):43-46.

[12] Khadkutkar DK, Kanthi VG. Therapeutic uses of Panchvalkal in different form, A review. Ayurlog Natl J Res Ayurveda Sci. 2014:1-5.

[13] Moguly G. et.al A contemporary approach on design, development, and evaluation of Ayurvedic formulation- Triphala Guggulu Ayu 2015: 318- 322.

Citation: H. Nakrani, "Clinical Effect of Kasisadi Taila in the Management of Post Operative Wound of Infected Sebaceous Cyst-A Case Report", International Journal of Medicinal Plants and Natural Products (IJMPNP), vol. 4, no. 1, pp. 22-25, 2018. http://dx.doi.org/10.20431/2454-7999.0401005

Copyright: () 2018 Authors. This is an open-access article distributed under the terms of the Creative Commons Attribution License, which permits unrestricted use, distribution, and reproduction in any medium, provided the original author and source are credited. 